DOI: https://doi.org/10.32839/2304-5809/2021-8-96-20

УДК $82-1 /-9$

Гайнігова Л.

Масариків університет, Філософрський фракультет, м. Брно

\title{
КОРОТКО ПРО РОЗВИТОК ЖАНРУ ЧИКЛІТ НА МАТЕРІАЛІ ТВОРІВ НАТАЛКИ СНЯДАНКО ТА СВІТЛАНИ ПИРКАЛО ${ }^{1}$
}

Анотація. У статті досліджуеться генеза цього подекуди нового жанру популярної літератури, який з'явився перший раз у дев’яностих роках в англомовній літературі («Щоденник Бріджит Джонс» з року 1996 британської авторки Гелен Філдінг), та описуеться його прояв у сучасній українській, популярній прозі для жінок. Здійснено аналіз наукових праць, які досліджують жанр чикліт (світова рецепція жанру, статті українських дослідниць). Ключова частина статті виходить з аналізу вибраних популярних жіночих творів українських авторок нового тисячоліття, зокрема романів Світлани Пиркало («Зелена Маргарита», «Не думай про червоне: Роман не для молодшого шкільного віку») та Наталки Сняданко («Колекція пристрастей, або Пригоди молодої українки»), під оглядом рис, типових для жанру чикліт і відношення цих творів до фремінізму та постфемінізму.

Ключові слова: чикліт, українська популярна література, література для жінок, нове покоління прозаїчек, Наталка Сняданко, Світлана Пиркало, фремінізм, постфемінізм.

Heinigova Linda

Masaryk University, Faculty of Arts, Brno

\section{A BRIEF HISTORY OF A LITERARY GENRE CHICK LIT IN UKRAINIAN LITERATURE (IN NOVELS BY N. SNIADANKO AND S. PYRKALO)}

Summary. It has been more than two decades since the first publication of the pioneering literary work in a genre which would be later called the chick lit; the novel was named after its main protagonist and it was published in the year 1996 - "Bridget Jones's Diary" by a British author Helen Fielding. However, the term chick lit had been used a year before Fielding's iconic heroine appeared in bookstores and libraries, it was an ironic title of Cris Mazza and Jeffrey DeShell's collection of short stories written by women "Chick Lit Postfeminist Fiction" (published in 1995). Ever since the emergence of Fielding's novel on that single, thirty-something, clumsy, funny and ironic Bridget Jones - a young British woman living in the megalopolis of London, who struggles with both her job and her personal life, there have appeared a quiet few of alike novels all over the Anglophonic Western world (novels by Sophie Kinsella, Candace Bushnell and others), and it was not so much later when a young generation of Ukrainian women-writers picked up the formula of a chick lit and and began writing same-spirited novels. The main protagonist of the chick lit novel would always be a woman between the age of twenty and thirty, often single, (well-)educated, usually working in media and often surrounded by her friends, who also function as her family. Although there is not an obligatory happy ending, a conclusion of these books is usually carried out in a positive way. The present study concentrates its interest on the emergence of this new, modern literary genre of women's prose since its appearance in the middle nineties in English written popular literature to the beginning of 2000s in Ukrainian literature written by women-authors, above all in novels of Natalka Sniadanko (,The Passion Collection, or The Adventures and Misadventures of a Young Ukrainian Lady“) and Svitlana Pyrkalo ("Green Margarita“ and „Don't Think about Red“) while demonstrating occuring elements of the new genre and pointing out its evident symbiosis with postfeminist trends in contrast to feminism which is being taken as an outdated movement or an ideology, no longer necessary in today's society.

Keywords: chick lit, Ukrainian popular literature, women's literature, generation gap, Natalka Sniadanko, Svitlana Pyrkalo, feminism, postfeminism

Постановка проблеми. У даній статті розгортаеться проблематика виникнення жанру чикліт від самого його початку в англомовній літературі до його появи в українській літературі. Завдяки новим дослідженням іноземних (американських, британських, німецких та інших) літературознавців (літературознавкинь) та соціологів (соціологинь), ми можемо побачити цілий феномен жанру чикліт у новому світлі.

Аналіз останніх досліджень і публікацій. Як уже говорить сама назва статті, цілий ряд учених про проблематику нового жанру чикліт писали та говорили з самого початку його появи, тобто 3 кінця дев'яностих років минулого століття; між науковцями 3 англомовного світу слід назвати принаймні дослідниць Кріс Мацца, Стедра- ні Гажевські, Сюзен Феррісс та Меллори Янг, або теж німецьку літературознавчиню Гайке Мізлер. Якщо йдеться саме про українське літературне середовище, то дослідженням та аналізом даної проблематики займалися та досі займаються багато українських дослідниць. Згадаймо хоч дослідження Мирослави Крупки, Марини Рябченко або Coфiї Філоненко та інші.

Мета статті. Основною метою даного дослідження є представлення жанру чикліт 3 погляду історичного та генологічного, з використанням компаративної методи при аналізі прозаїчних творів сучасних український письменниць Наталки Сняданко та Світлани Пиркало.

Виклад основного матеріалу. На початку другого тисячоліття в українській літературі

\footnotetext{
1 This publication was written at Masaryk university as part of the project Ztracení na hraně staletí: Mladí lidé v současných prózách postkomunistického prostoru number MUNI/A/1360/2021 with the support of the Specific University Research Grant, as provided by the Ministry of Education, Youth and Sports of the Czech Republic in the year 2021.
}

(C) Гайнігова Л., 2021 
сорормувалося нове покоління молодих прозаїчек, що продовжує літературні тенденщії, розпочаті в попередніх роках. Із творчості молодої ґенерації письменниць, утім, зникла фреміністична ангажованість, притаманна літературі дев'ятдесятих років. I хоча тексти сучасних авторок не $є$ першочергово та програмово фреміністичними, вони безумовно ілюструють жіночий досвід у сучасному українському суспільстві.

Характерним спільним первнем у творчості багатьох українських авторок, що дебютували після 2000 року, досі є сильна суб'єктивація та автобіографізм [16, с. 279-284], однак у прозі частіше доходить до змішування кодів високого та популярного мистецтва.

Зародження т.зв. «чикліту» - нового літературного жанру, осучасненого типу популярного чтива для жінок - тісно пов'язане з популяризаційними тенденціями в культурі та гендерному дискурсі загалом.

Уперше термін чикліт (англ. chick lit) було використано 1995 року американською письменницею Кріс Мацща та її колегою, прозаїком Джефрорі ДеШеллем у назві антології тодішньої сучасної жіночої прози, виданої за їх редакцією «Чикліт: Постореміністична художня література» (англ. Chick Lit: Postfeminist Fiction). Пізніше у статті «Хто сміеться тепер? Стисла історія чикліту й збочення жанру» (англ. Who's Laughing Now? A Short History of Chick Lit and the Perversion of a Genre), в якій досліджується генеза чикліту, а також йдеться про наведену збірку оповідань, К. Мащца прокоментувала вибір назви наступним чином: «У цьому полягав іронічний задум нашої назви. Замість підтримки образу жінок як залицяльниць і легковажних істот ми хотіли навпаки взяти часткову відповідальність за цей упереджений і довготривалий стереотип» ${ }^{2}$. Тож початково термін «чикліт» було замислено як іронічне посилання на прояви постоеміністичних тенденщій у літературі.

Постфеміністичними тенденціями зазвичай називають критичну переоцінку ідей емансипації та фремінізму, дистанціювання не лише від правил патріархального суспільства, але й віднедавна від західних фреміністичних ідеалів. У дев'ятдесятих роках втілення ідей фемінізму (наприклад, беззаперечність права жінок на працю, рівноцінна фінансова винагорода за iï виконання чи право розпоряджатися власним тілом) сягнуло на Заході цілком нового рівня сприйняття і схвалення [10, с. 18]. Постфемінізм на відміну від другої і третьої хвилі фемінізму розуміється багатьма дослідниками радше як соціокультурний феномен, аніж політичний рух зі своєю ідеологією. Хоча громадськість інколи сприймає постфемінізм як четверту, самобутню хвилю фреміністичних рухів, його слід було б розглядати як паралельну фрорму фемінізму третьої хвилі ${ }^{3}$. Українська дослідниця літератури Марина Рябченко слушно зауважуе, що посторемінізм можна розуміти як осучаснену критику фремінізму: постфеміністки виказують небажання сучасної жінки підпорядкувати власне життя пуританській та чоловіконенависницькій ідеології феміністок; постфеміністки вважають, що жінка має право вибору, чи присвятити своє життя побудові успішної кар'єри, або вирішити утворити родину та стати домогосподаркою [5, с. 290-295]. Постфемінізм одночасно протистоїть позірному сприйняттю жіночої сексуальності та узагальненню жінок як жертв системи - сексуальність жінки у ньому підноситься, а не засуджуеться.

Сьогодні, під оглядом літературних критиків, істотними для обговорюваного жанру є його тематика, головний герої, цільова, аудиторія, стиль оповідання. Чикліт є жіночою популярною літературою, зорієнтованою на жіночу аудиторію. Протагоністкою виступає молода незаміжня жінка віком від двадцяти до тридцяти років, яка намагається сумістити кар'єру й особисте життя [1, с. 3]. Як навмисно іронічна назва антології спричинила появу жанру, якому цей термін приписують сьогодні? Провина лежить передусім на американському культурному критикові Джеймсові Волкотту та його статті, випущеної для тижневика The New Yorker у квітні 1996 року - «Почуй мій нявкіт: Морін Дауд і сходження постфеміністичного чикліту» (англ. Hear Me Purr: Maureen Dowd and the rise of postfeminist chick-lit). У ній автор пише про новий жанр поплітератури для жінок у стилі газетних колонок. Пізніше британський книжковий ринок відреагував на Волкоттову інтерпретацію чикліту як популярної постореміністичної літератури, згадавши тоді щойно опублікований роман Гелен Філдинг «Щоденник Бріджит Джонс» $(1996)^{4}$, що актуалізував жанрову характеристику чикліту [8, с. 21-24]. У наступних роках британський та американський книжкові ринки охопила хвиля схожих текстів ${ }^{5}$.

Спільним знаменником завжди була жінкаавтор, а головною героїнею - молодша жінка, яка мешкає у великому місті. Звичною тематикою стали міжособистісні стосунки (гетеросексуальний любовний роман, ставлення героїні до iï партнерів, котрі замінюють родину), реалістичне зображення сексуального життя жінки; обов'язкова наявність грайливого та гумористичного тону оповідання в першій особі, а також невдоволення власним фізичним виглядом і завзяття до самовдосконалення. Історія кохання майже завжди переплітається 3 кар'єрним зростанням (часто-густо протагоністка працюе в якомусь відгалуженні моди або в медіа).

Стефрані Гажевські, американська літературознавиця, наголошує на невід'ємності сучасного жанру й літературної традиції т.зв. вихов-

${ }^{2}$, "This was the ironic intention of our title: not to embrace an old frivolous or coquettish image of women but to take responsibility for out part in the damaging, lingering stereotype. "[8, c. 18].

${ }^{3}$ С. Гажевські вважае, що переконання феміністок третьої хвилі у застарілості другої хвилі фремінізму корелюе з ідеями, які приписують постфемінізму [5, с. 149-186]. За словами Гайке Мізлер, постфемінізм у свою чергу є гіперонімом на означення багатьох поглядів поза феміністичним рухом, які проявилися на початку 1990-х рр. [10, с. 25], чим підкріплюе неодноразові припущення про їх одночасне виникнення з фемінізмом третьої хвилі.

${ }^{4}$ В академічних колах «Щоденник Бріджит Джонс» (Bridget Jones's Diary, 1996) часто називають єдиним праобразом жанру чикліт [1, с. 1-15].

5 Серед уже «канонізованих» чикліт-романів відмітимо бодай «Секс і місто» (1996) американської журналістки Кендес Бушнелл, «Зізнання шопоголіка» (1999) Софі Кінселли і «Диявол носить "Прада"» (2003) Лорен Вайсбергер. 
ного роману ${ }^{6}$, який на початку дев’ятнадцятого століття культивувала, наприклад, англійська письменниця Джейн Остін. Гажевські вбачає схожість центральної романтичної сюжетної лінії та критичне, стримане ставлення до зв'язку між жінкою та чоловіком [5, с. 8]. Утім, найміцніший зв'язок авторка помічає між чиклітом i оригінальними любовними романами (у чеській літературній традиції - červená knihovna, укр. червона книгозбірня) [4, с. 29-46]. До цього вона додає: «На відміну від арлекінок, чикліт переміщує елементи любовного роману [червоної книгозбірні] до міського середовища [...]»7 . На думку досліднищі, жанр чикліт містить безумовно менше романтики, ніж його попередник. Зображення міжособистісних стосунків навпаки $€$ реалістичнішим, з чим пов'язано і відсутність невідворотного гепіенду - лише малий відсоток книжок закінчуеться укладенням шлюбу героїні та її обранця [4, с. 29-46]. Погоджуючись із тезою Гажевської про зв'язок старіших, традиційних жанрів літератури для жінок та новішого жанру чикліт, який, у власний спосіб розвиваючи своїх попередників, йде по їхніх стопах (нехай і будучи осучасненим), ми вважаємо за потрібне додати, що більше ототожнюємо свою думку з ідеєю Гайке Мізлер. Вона стверджуе, що частий відхід чикліту від головної сюжетної лінії унаочнюе його схожість радше з виховним (нім. Bildungsroman), аніж з любовним романом, бо в центрі уваги лежить особистісний розвиток героїні, розглянутий зсередини [10, с. 31]. Історія кохання в чикліті стоїть позаду, що принципово відрізняе його від червоної книгозбірні. У любовному романі панівною тематикою є зображення романтичних стосунків гетеросексуальної пари - історія описує поступове зближення персонажів і зазвичай підсумовується або щасливим шлюбом, або принаймні освідченням головних героїв у вічному коханні [11, с. 86-89]. При цьому, децентралізація любовного зв'язку в жанрі чикліт - це не єдина відмінна, хоч і беззаперечна риса, коли йдеться про відхід від класичних любовних романів. На відміну від них, героїня чикліту не ідеальна, її недоліки може бути пов'язано як з характером, так і з зовнішністю. Не в останню чергу, аби твір було віднесено до чикліту, його тексту не мусить бракувати гумору й (само-)іронії - це більше віддаляе оповідання традиційних любовних романів, де розважальна фрункція тексту відсутня.

Типовими атрибутами жанру чикліт наділена i деяка проза українських авторок покоління двотисячників, зокрема тексти Світлани Прикало та Наталки Сняданко, що літературно дебютували на самому початку нового тисячоліття. Так, першотвори цих письменниць часто пов'язані 3 поетичними практиками сучасного жанру жіночої літератури: автобіографрічність, оповідання від першої особи (з перспективи гомодієгетичної оповідачки), сповідальний стиль (потужна суб'єктивізована фрабула), переважан- ня теми міжособистісних стосунків та зображення нового жіночого досвіду в сучасному, мінливому світі.

У минулому першотвір уродженки Полтавської області Світлани Пиркало «Зелена Маргарита» уже встигали охрестити першим українським твором жанру чикліт. Уперше повість було опубліковано 2000 року київським видавництвом «Смолоскип». Повість стала бестселером i, як пише літературний критик Александр Кратохвіл, першим українським попроманом [6, с. 5-6]. Про успіх книжки серед читачів свідчить і те, що до ціеї миті її перевидано двічі.

Головною героїнею та гомодієгетичною оповідачкою повісті "Зелена Маргарита" є недавня випускниця Київського університету й новинарка (чи радше авторка, що пише на замовлення рекламні оголошення, рецензії косметики та харчувальних закладів) Марина Погрібна, яка на час подій мешкає в Киеві. У вступній частині оповідачка скромно визнає, що їі книжка не є великим романом, а лише опис кількох звичайних днів у їі житті ${ }^{8}$. На сторінках повісті читач стежить за життям героїні у перебігу неповних трьох весняних тижнів кінця двадцятого століття. За своєю композицією текст розділено на окремі дні, де оповідачка виписуе повсякденні радощі й турботи, чим у значній мірі нагадуе щоденникову форму літературного витоку жанру чикліт «Щоденник Бріджит Джонс». Щоправда, на відміну від традиційного роману чикліт, героїня "Зеленої Маргарити» є щасливою у партнерських стосунках, і хоча їі обранець у книзі не dirypye, Марина часто згадуе про нього: "До речі, треба подзвонити батькам мого коханого і подякувати їл за нього. Якби не він, я б жила удвох із котоли.

На відміну від типової героїні чикліту, Марині напевно не бракуе здорової впевненості. Читач, ознайомлений з поетичними прийомами, характерними для чикліту, теж не знайде в книзі аж так багато гумору й самоіронії, як можна було $б$ очікувати Це пов'язано 3 тим, що повість написано у грайливому та легкому тоні, за стилістикою - мов колонки в часописі. Якщо у вступній частині статті ми зазначили, що жанр є типовим проявом постфемінізму, неможна оминути, як себе проявляе в його дусі Марина Погрібна - вона постійно декларує, що є фреміністкою, оскільки [sic!] читає фрілософрські есеї Оксани Забужко, радить читачеві ознайомитися з Симоною де Бовуар і сама написала статтю про фреміністичні міри (вбудована до книжного тексту), але з іншого боку визнає:

"Є й інша причина, чому не всіл жінкал так уже потрібні ті права. Права - ие відповідальність. Право салій забезпечувати себе литеріально означає, шо вже не вийде так солодко й безтурботно висіти на чоловічій шиї [...]»110.

Другим літературним твором Світлани Пиркало став роман 2004 року «Не думай про чер-

${ }^{6}$ В англомовному середовиші також вживається термін «роман звичаїв» (англ. novel of manners).

„Chick lit transports elements of the romance into an urban setting, as opposed to Harlequins [...].“ [4, с. 29-46]. У цьому перекладі слово «арлекінки» застосовуеться або на позначення, або синонімічно до любовних романів.

8 „Ця історія - не гостросюжетний роман, а просто оповідь про пару-десять днів, проведених мною, - кілька звичайних днів"“[13, с. 2].

9 "До речі, треба подзвонити батькам мого коханого і подякувати ӥл за нього. Якби не він, я б жила удвох із котол“"[13, с. 43].

${ }_{10}$ "С й інша причина, чолу не всім жінкам так уже потрібні ті права. Права - ие відповідальність. Право салій забезпечувати себе матеріально означає, що вже не вийде так солодко й безтурботно висіти на чоловічій шиі [...]“[13, с. 46]. 
воне: Роман не для молодшого шкільного віку», який частково продовжуе «Зелену Маргариту». Своєю структурою та стилем оповідання роман ніяк не відрізняється від авторського дебюту, однак загалом, на наш погляд, постає більш (само-)іронічним та гумористичним ${ }^{11}$, наближаючись до британських та американських чикліттекстів. Так само, як і в першотворі, оповідання здійснюеться від першої особи, гомодіегетичної оповідачки та головної героїні Павліни Стопудів - двадцятип'ятирічної, незаміжньої, амбітної новинарки, яка переїжджає з Києва до Лондона, де їй запропонували місце закордонної кореспондентки $B B C$ News. Протягом цілого роману наблюдаємо постійні зусилля Павліни возз'єднатися зі своїм колишнім коханцем, американським саксофоністом Джимом, з яким вона познайомилася ще студенткою сім років тому на музичному фестивалі в Луџьку. Таким чином, читач може припустити, що вигідна пропозиція працевлаштування не була єдиним стимулом для переїзду Павліни до Лондона, до того ж героїня часто зізнається у незгаслих та пристрасних почуттях музикантові ${ }^{12}$. Хоча їхня зустріч відбудеться після багатьох невдалих спроб, Павліна усвідомлюе, що їі вабить не щире почуття до коханого, а скоріше викривлений образ минулого й звичайна туга за емоційною близькістю. Мирослава Крупка, літературознавиця, яка у своїй професійній діяльності приділяе особливу увагу українській жіночій літературі, висловила думку, що у романі С. Пиркало ідеалізацію очей у любовних стосунках треба розуміти радше як франтазію про кохання, а не бажання їі реалізації. Сенсом життя стають не самі почуття, а прагнення можливості їх досягнути, очікування любові [7, с. 73-79].

Центральною темою роману однак лишається, як це буває у текстах, які належать до жанру чикліт, зображення щоденного життя молодої, незалежної жінки. Окрім опису життя в британському мегаполісі (час, проведений 3 друзями, знайомство 3 новими людьми, стосунки на роботі, посиденьки в різноманітних барах, вечірки, шопінг) щире вираження власної сексуальності є характерним не лише для жанру чикліт, а й загалом для нової жіночої прози ${ }^{13}$.

Павліна неодноразово зізнається, що не дістає тілесної насолоди. Цю тему вона обговорюе 3 друзями чи сповідаеться читачам ${ }^{14}$ у монолозі. Щойно вона вирішує діяти, секс, як задоволення суто фрізичної потреби, перетворюеться на засіб, за допомогою якого жінка досліджує власну ідентичність. Таким чином, у тексті руйнуються застарілі гендерні стереотипи про жінок як простих об'єктах статевої активності. 3 іншого боку, треба зазначити, що сексуальні сцени у жанрі чикліт зрідка коли зображуються яскраво і детально, а бувають найчастіше описані стисло і предметно ${ }^{15}$.

Важливою ознакою роману є його автобіографічність. Як слушно зауважуе Марина Рябченко, автобіографічність (або ж автобіографрізм, див. вище) найбільше сигналізуе пряма назва свого імені або зрима алюзія на нього [16, с. 279-284]. На наш погляд, утім, найбільш виразним проявом автобіографрізму в романі опиняеться точна дата народження та місце, які збігаються як з авторкою, так і з її протагоністкою ${ }^{16}$.

Крім того, вони обидві вивчали фрілологію в Київському національному університеті імені Тараса Шевченка. Пиркало в дійсності переїхала на початку 2000-х рр. до Лондона, де, обійнявши посаду новинарки BBC News, провела майже десять років.

Істотним відхиленням від жанру чикліт є присутність у романі роздумів щодо реальних подій - смерті двох друзів і пов'язаного з цим стеження за політичним перебігом на Близькому Сході протягом 2000-х років.

Роман західноукраїнської письменнищі Наталки Сняданко "Колекиія пристрастей або Пригоди лолодої українки» було вперше опубліковано 2001 року львівським видавництвом Піраміда. Кількома роками пізніше в Україні дочекалися не лише на друге видання (харківське видавництво "Фоліо», 2008), а й переклад іншими мовами (текст було перекладено чеською, польською, німецькою та російською мовами; частину роману було перекладено англійською та видано у збірці української жіночої прози "Herstories: Anthology of New Ukrainian Women Prose Writers»17), що принаймні доводить його популярність серед читачів.

Наратив роману презентуе іронічну, значною мірою жартівливу, динамічну й читабельну розповідь галицької дівчини про колекцію чоловіків у своєму житті. Викладений у формі особистого щоденника, роман складається 3 семи розділів, у яких проаналізовано формування особистості головної героїні - від дитячих років до ранньої зрілості, що відрізняе його від прозових творів Світлани Пиркало і типових представників чикліту. Тут варто згадати гіпотезу Г. Мізлер, яка вказуе [10, с. 31] на очевидні збіги наративного розвитку в жанрі чикліт і виховного роману, про

11 „[...] можливо, я доживуся колись до такої старості, що доведеться іти в Сохо $і$ купувати собі штучний член, шоб просто не забути, як він виглядае“ [14, с. 27].

12 „Я побачила чоловіка з чорнила очима, погляд яких мені сниться досі. [...] У мене забрало сім років, шоб приїхати до міста, де він колись жив - тільки щоб збагнути, шо його тут більше нелає. [...] але готова витратити ще скільки завгодно років і змінити скільки завгодно краӥн, аби його побачити“" [14, с. 49].

${ }^{13}$ Софія Філоненко звертае увагу на цілковиту відсутність у 1980-х рр. сексуальної проблематики в жіночій прозі. Стосунки між чоловіками і жінками було зведено до романтичного, асексуального рівня, а тему жіночої сексуальності взагалі замовчано. Тодішня жіноча проза була позафеміністичною, себто літературою патріархально налаштованих жінок, чия жіночність формувалася за радянської ери. Таким чином, ця література відображала всі стереотипи радянської жінки. Наприклад, чоловік був для героїні центром всесвіту, жінка ж пізнавала себе лише у світлі його емоційної прив'язаності, суто як об'єкт [2, с. 11-28]. Помітні зміни в гендерному дискурсі почали з'являтися в 1990-х рр., коли українська література поповнилася низкою нових, вагомих авторок, чимало з яких активні до сьогодні.

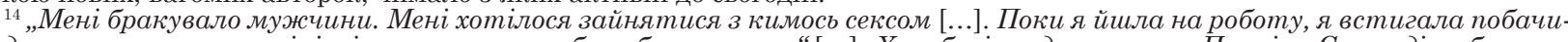
ти десятки гарних чоловіків, із якими можна було б переспати“ [...] „Хто б міг подумати, що Павліна Стопудів у багатомільйоному місті не знатиме, з ким переспати“" [14, с. 79].

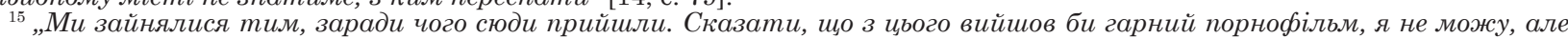
перебирати мені не доводилося" “[14, с. 85].

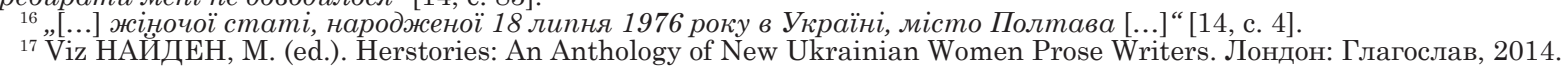


які зазначено вище. Роман приховує в собі виразно автобіографічні риси. Так, одне лиш ім'я протагоністки, Олеся Підобідко, свідчить про alter ego письменниці. Іншою характерною рисою автобіографрічності є вивчення Олесею української філології у Львівському університеті, а також перебування в західнонімецькому Фрайбурзі та Баден-Бадені у дев'ятдесятих роках, що майже нічим не відрізняе її від авторки.

Олеся Підобідко е молодою, емансипованою, розумною та впевненою в собі жінкою. Інтелект і самовпевненість, якими Олеся пригнічуе будького і за будь-якої ситуації, її відділяє від типової героїні чикліту. Втім, час від часу вона кепкуе 3 себе, роблячись людянішою та ближчою до героїнь жанру:

"У перші дні мій «середньо-початковий рівень [німецької мови] виявляв себе переважно в толу, ио я брала в руку яблуко і старанно повторювала за форау Де Ллфборте: “дер апфбель”, потіл міняла яблуко на грушку $i$ знову старанно повторювала: “ді бірне”, а потіл, щоб продемонструвати свою не повну вже дрілучість, хапала банан і радісно посліхаючись, повідолляла: "айне банане"” [17, с. 123].

Як ми вже казали, жанр чикліт часто згадується в тандемі з постфеміністичними тенденціями. Британська сощіологиня і теоретикиня культури Анджела МакРоббі у свій монографії "Наслідок белінізлу: гендер, культура та сочіальна злінал (2009) визначає постфеміністичні настанови як антифеміністичні, однак парадоксально засновані на припущенні, що фремінізм був проявом здорового глузду [9, с. 40, 130]. Олесю Підобідко, як і Марину Погрібну чи Павліну Стопудів, можна вважати через її погляди постфеміністкою: "Після прочитання всіх" наведених вище історій у декого може скластися враження, шо героїня надто вже несвідоло ставиться до питань, пов'язаних з емансипацією. У когось навіть може зародитися підозра, що авторка - затята ббеліністка. Або ж навпаки, шо вона - проти елансипації. [...] Толу відразу уточню, шо ототожненнял "пристрасть $i$ жінка" я зовсіл не хочу продовжувати довгий ряд статевих дискрилінаиій, яких жіноитву довелося зазнати протягол усієї історї людства, як не лию на увазі й представлення жінки лише як об'єкта сексуальної уваги. Так, ніби пристрасть ложе виникати тільки до жінки. Хоча ясна річ, у боротьбі за права жінок найважливіше - вчасно зупинитися" [17, с. 223-224].

У іншому місці роману героїня сперечається зі своїм німецьким приятелем, переконаним фреміністом, про необхідність самого фремінізму - з численних Олесиних поглядів випливає, що, погоджуючись із засадничим ідеями, вона стверджує, що жінка завжди мала б мати право вибору:

"[...] Але мені здається, шо фбелінізл - ие таке салие перебільшення, як і патріархат, просто в інший бік. Сала потреба доводити те, шо жінка - настільки ж повноцінна особистість, як і чоловік, принизлива. [...] Усі ми різні, $і$ чолу б не припустити, що деяким жінкам подобається бути залежнили від їхніх чоловіків, шо для них сіл'я важливіша за салореалізацію, роботу $i$ все інше? [...] Але навішо, коли ие влаштовує

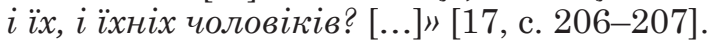

Висновки i пропозиції. Жанр чикліт, як прояв постореміністичних тенденцій в культурі та суспільстві, став із початком нового тисячоліття часто обговорюваним френоменом. Про його ґенезу та невідворотній занепад, характерні риси, довготривалість і різні піджанри написано незлічені праці у багатьох країнах по всьому світу. 3 одного боку, про чикліт відгукуються схвально через його «інший», реалістичніший погляд на світ, із яким себе ідентифрікуе чимало сучасних жінок. 3 іншого боку, через стереотипові оповідні практики та шаблонових персонажів (особливо чоловічих) його нерідко відносять до масової літератури сумнівної якості, до пляжного чтива, інколи до ролі арлекінок нової доби.

Нова доба вимагає нових підходів, незалежно від того, йдеться про зміни у суспільстві чи культурі. Як бачимо вище, письменницьке покоління українських двотисячників (двотисячниць) слідуе тенденціям, розпочатим у жіночій прозі в дев'ятдесятих роках. Однак через те у творчості міленіалок присутні очевидні спроби змінюватися, просуватися далі. У новому тисячолітті вже мало кого шокують раніше табуйовані, суто жіночі теми, такі як пологи, аборти, оргазм, фрригідність або менструація. Зрідка хто сьогодні обурюеться вульгаризмам з під-пера авторки порівняно з серединою дев'ятдесятих років [sic! ${ }^{18}$. У літературі ніхто вже навіть не зупиняеться перед нецензурованою сексуальністю, перед яскраво, майже натуралістично зображеними сценами сексу. Декотрі з прозаїчек відчули зміни в гендерному дискурсі та вирішили втілити їх на папері. Тоді в українській літературі з'явився чикліт. Будьмо однак вельми обережними в своïх твердженнях, оскільки говорити про френомен чикліту в українській літературі як про цілковито сформований, самобутній жанр, було б щонайменше неточно - правильніше констатувати, що декотрі його елементи унаочнюе жменька прозових творів українських письменниць. Наприклад, трансформація любовного роману, яка надійшла з Британії (або, якщо взяти друге за згадуваністю джерело жанру чикліт - "Секс $i$ мiсто" (1996), то, мабуть, доречно казати про походження цього явища в англомовній літературі в цілому). Уперше про жанр чикліт в українській літературі розповіла вчена-літературознавиця Содрія Філоненко. Це тривало недовго, і жанр привернув увагу інших експерток (нікого не має дивувати, що більшість зацікавлених є жінками), таких яких Марина Рябченко, Олена Романенко і Мирослава Крупка. Окрім того, соціологиня Зоя Шевченко включила слово «чикліт» до свого Словника тендерних терлінів ${ }^{19}$.

\footnotetext{
${ }^{18}$ Скандал тоді спричинив прозовий дебют Оксани Забужко «Польові дослідження з українського сексу» (1996). Літературні критики (важливо підкреслити, передусім чоловіки) висловили, серед усього іншого, своє невдоволення мовними засобами, використаними авторкою в романі: «Головний аргулент критики: як могла жінка дозволити собі таку відвертість, лайливі вислови та зображення еротихних сиен? (Те, що давно дозволяється будь-якому чоловікові» [12, с. 181-187].

19 ШЕВЧЕНКО, Зоя. Словник гендерних терлінів. Черкаси, 2016. [Електронне джерело]. Доступне за посиланням: http://a-z-gender.net/ua/wp-content/uploads/2018/05/Slovnyk-gendernyh-terminiv.pdf
} 
Обидві письменниці (майже однолітки ${ }^{20}$ ), твори яких ми обрали для порівняльного аналізу, дебютували на самому початку нульових років. Для кожної це були їхні першотвори (за винятком роману "Недумай про червоне»). Усі три тексти бодай частково відповідають характеристикам жанру чикліт. "Зелена Маргарита", "Колекція пристрастей або Пригоди молодої украйнки» та "Не дулай про червоне» е передусім гумористичною, подеколи іронічною (іноді навіть саркастичною) жіночою прозою популярної літератури, для якої характерні надзвичайно суб'єктивізовані фабули, що до певної міри нагадують записки у щоденнику. Протаґоністки романів - Марина Погрібна, Павліна Стопудів та Олеся Підобідко - це молоді емансиповані жінки, що мешкають у великих містах. Їх можна вважати майже взірцевими героїнями чикліту, а через автобіографрічність творів Пиркало і Сняданко - alter ego'oм письменниць.

Вони не бояться висловити свої погляди і здебільшого вважають фемінізм старомодним рухом, нездатним задовільнити потреби сучасної жінки. I Марина, і Павліна, і Олеся без докорів сумління насолоджуються своєю сексуальністю i відверто говорять про це, не боячись подвійного сексуального стандарту, який, на думку МакРоббі [9, с. 10-11], е важливим аспектом постфеміністичних тенденцій. Крім того, усі вони, обожнюючи фінансову незалежність, більш ніж спроможні забезпечити себе. Героїні Світлани Пиркало, як і декотрі їхні попередниці ${ }^{21}$, репрезентують споживацький спосіб життя, охоче тішаться дорогим предметом одягу чи косметикою, а також часто витрачають великі суми в барах, клубах чи ресторанах.

На відміну від любовних романів, у центрі уваги цієї прози відсутня любовна лінія, що мала б неминуче привести до гепіенду у вигляді весілля, освідчення в нескінченному коханні та вірності аж до гробу.
Як правило, чикліт надає реалістичніше зображення романтичних стосунків чи життя незаміжньої жінки, проте ані в новелі «Зелена Маргарита", ані в романах "Не думай на червоне» та "Колекиї̈ пристрастей..." - проза Світлани Пиркало закінчуеться більш-менш відкрито - читач не може передбачити, що Марина задоволена своїм положенням. На неї чекае хіба що нелегке рішення щодо здобуття освіти за кордоном в осяжному майбутньому. Наприкінці роману «Не думай про червоне» Павліна залишається сама, проте висловлюе надію, що все обернеться на краще, а Олеся, персонаж Сняданко, ще на сторінках роману встигне вийти заміж, але про зміну свого сімейного стану вона згадуе лише мимохідь, а читачеві не підтверджуе жодних подробиць.

На мовному рівні жанр чикліт, включно з відібраними нами творами, постае новаторським і спонукае до вживання експресивних виразів, грубощів. Як у прозі Світлани Пиркало, так і романі Сняданко подибуемо елементи суржика, а також вулыаризми. Сняданко охоче використовуе галицизми, тоді як Пиркало притаманне неодноразове вживання англіцизмів.

Факт лишаеться фоктом - чикліт належить до жанру популярної літератури. 3 огляду на це його тематика багатьом критикам та вимогливим читачам може здатися поверховою, персонажі шаблоновими, а оповідна цінність - близькою до нуля. Проте, якщо ми глибше поринемо в тексти, то дійдемо висновку, що безумовна приналежність чикліту до масової культури аніскільки його принижуе. Він без проблем виконуе свою розважальну, а іноді також соціальну й пізнавальну функщії. Додаймо до цього властивий чикліту ескапізм, можливість ототожнення читачки з героїнею або, як зазначає Мізлер, втіху, що може полягати в ознайомленні з вигаданим світом, дуже схожим на той, в якому живе сама читачка, і тоді ми зможемо зрозуміти, чому цей жанр так цінуеться читачками ось уже понад два десятиліття.

\section{Список літератури:}

1. Гажевські С. Традиція та зміщення в новому романі манерів. In: Чикліт: Нова жіноча проза (ед. Феррісс С., Янг М.). Нью-Иорк : Роутлідж, Тейлор енд Френцис Груп, 2006.

2. Гажевські С. Чикліт і постфемінізм. Шарлоттсвілл : Університет Вірджінія Пресс, 2011.

3. Кратохвіл А. Поп-література: покоління 90+. Критика. Київ, 2009. Ч. 5-6.

4. Крупка М. Художні версії любовних драм у сучасному прозовому дискурсі (Романи О. Забужко, I. Карпи, С. Пиркало). Київ : Слово і час, Літературна критика, 2007. Ч. 7.

5. Мащца К. І хто тепер сміеться? Стисла історія жанру чикліт й збочення жанру. In: Чикліт: Нова жіноча проза (ед. Феррісс С., Янг М.). Нью-Йорк : Роутлідж, Тейлор енд Френцис Груп, 2006.

6. МакРоббі А. Наслідки фемінізму: Гендер, культура та соціальні зміни. Лондон : Сейдж, 2009.

7. Мізлер Г. Культурна політика жанру чикліт: Популярна фікція, постфемінізм і репрезентація. Нью-Йорк : Роутлідж, Тейлор енд Френцис Груп, 2017.

8. Моцна Д., Петерка Й. Енциклопедія літературних жанрів. Прага/Літомишл : Пасека, 2004.

9. Павличко С. Виклик стереотипам: Нові жіночі голоси в сучасній українській літературі. In: Фемінізм (ед. Агеєва В.). Київ : Видавництво Основи, 2002.

10. Пиркало С. Зелена Маргарита. 2000. URL: https://shron1.chtyvo.org.ua/Pyrkalo_Svitlana/Zelena_Marharyta. pdf?PHPSESSID=dfa001b011407cb81ca92f4df755ee75

11. Пиркало $\quad$ C. Не думай про червоне : Роман не для молодшого шкільного віку. 2004. URL: http://maxima-library.org/knigi/year/b/213917 (пагінація 1-158).

12. Рябченко М. Елементи чикліт прози в сучасній українській літературі (на матеріалі творів Наталки Сняданко, Світлани Пиркало). Славянськія літератури й кантйексце сусетнай. Мінськ, 2011.

13. Рябченко М. Жанрова дифузія в сучасній українській прозі (на матеріалі творів Н. Сняданко, М. Соколян, С. Пиркало). Літературознавчі студії, 2013.

14. Сняданко Н. Колекція пристрастей, або Пригоди молодої українки. Харків : Фоліо, 2008.

\footnotetext{
${ }^{20}$ Світлана Пиркало (*1976), Наталка Сняданко (*1973).

${ }^{21}$ Один з найвідоміших романів чикліту - «Зізнання шопоголіка» (1999) Софі Кінселли, де головна героїня є взірцевим утіленням споживацького стилю життя.
} 
15. Феррісс С., Янг М. Чикліт: Нова жіноча проза. Нью-Йорк : Роутлідж, Тейлор енд Френцис Груп, 2006.

16. Філоненко С. Концепція особистості жінки в українській жіночій прозі 90-х років ХХ століття. Київ, Ніжин : ТОВ Видавництво «Аспект Поліграф», 2006.

17. Філоненко С. Масова література в Україні Дискурс/гендер/жанр. Донецьк : Ландон XXI, 2011.

\section{References:}

1. Harzewski, Stephanie (2006) Tradition and Displacement in the New Novel of Manners. In: Chick Lit: The New Woman's Fiction (ed. FERRISS, Suzanne and Mallory YOUNG). New York: Routledge, Taylor and Francis Group.

2. Harzewski, Stephanie (2011) Chick Lit and Postfeminism. Charlottesville: University of Virginia Press.

3. Kratochvil, Aleksander (2009) Pop-literatura: pokolinnya 90+. Krytyka. Kyiv, pp. 5-6.

4. Krupka, Myroslava (2007) Chudozhni versii lyubovnych dram u suchasnomu prozovomu dyskursi (Romany O. Zabuzhko, I. Karpy, S. Pyrkalo). Kyiv: Slovo i chas, Literaturna krytyka, 2007, p. 7.

5. Mazza, Cris (2006) Who's Laughing Now? A Short History of Chick Lit and the Perversion of a Genre. In: Chick Lit: The New Woman's Fiction (ed. FERRISS, Suzanne and Mallory YOUNG). New York: Routledge, Taylor and Francis Group.

6. McRobbie, Angela (2009) The Aftermath of Feminism: Gender, Culture and Social Change. London: Sage.

7. Mißler, Heike (2017) The Cultural Politics of Chick Lit: Popular Fiction, Postfeminism, and Representation. New York: Routledge, Taylor \& Francis Group.

8. Mocna, Dagmar a Josef PETERKA. Encyklopedie literárních žánrů. Praha/Litomyšl: Paseka, 2004.

9. Pavlychko, Solomiya (2002) Vyklyk stereotypam: Novi zhinoci holosy v suchasniy ukrainskiy literaturi. In: Feminism (ed. AHEIEVA, Vira). Kyiv: Vydavnyctvo Osnovy.

10. Pyrkalo, Svitlana. Zelena Marharyta (2000) [online]. Available at: https://shron1.chtyvo.org.ua/Pyrkalo_Svitlana/ Zelena_Marharyta.pdf?PHPSESSID=dfa001b011407cb81ca92f4df755ee75

11. Pyrkalo, Svitlana (2004) Ne dumaj pro chervone: Roman ne dlya molodshoho shkilnoho viku [online]. Available at: http://maxima-library.org/knigi/year/b/213917

12. Riabchenko, Maryna (2011) Elementy «chicklit» prozy v suchasniy ukrainskiy literaturi (na materiali tvoriv Natalky Sniadanko, Svitlany Pyrkalo). In: Slavjanskija literatury j kantjeksce susvetnaj. Minsk.

13. Riabchenko, Maryna (2013) Zhanrova dyfuziya v suchasniy ukrajinskiy prozi (na materiali tvoriv N. Sniadanko, M. Sokolyan, S. Pyrkalo). Literaturoznavchi studiii.

14. Sniadanko, Natalka (2008) Kolekciya prystrastey, abo Pryhody molodoyi ukrainky. Kharkiv: Folio.

15. Ferriss, Suzanne and Mallory Young (2006) Chick Lit: The New Woman's Fiction. New York: Routledge, Taylor and Francis Group.

16. Filonenko, Sofiia (2006) Koncepciya osobystosti zhinky v ukrajinskiy zhinochiy prozi 90-kh rokiv XX stolittya. Kyiv, Nizhyn: TOV Vydavnyctvo «Aspekt Polihraf».

17. Filonenko, Sofiia (2011) Masova literatura v Ukraini: Dyskurs/gender/zhanr. Doneck: Landon XXI. 